\title{
Ny udgave af en velskreven grammatiksucces
}

\author{
BoganMELDELSE
}

DOI: https://doi.org/10.30752/nj.80382

Bill T. Arnold og John H. Choi, A Guide to Biblical Hebrew Syntax, 2nd edn (Cambridge University Press, 2018), 252 pp. ISBN 9781107434967

Denne engelsksprogede lærebog med titlen $A$ Guide to Biblical Hebrew Syntax udkom oktober 2018. Det er andenudgaven af et værk fra 2003. Den nye udgave er en videnskabelig opdatering af den første og har tillige nye afsnit om blandt andet pronominer samt tilføjelser til noteapparatet og bibliografien.

Bogen er skrevet af Bill T. Arnold (professor i GT og hermeneutik på Asbury Theological Seminary i USA) og John H. Choi (nu afdød; han var PhD i hebraisk og beslægtede studier fra Hebrew Union College).

Mens de introducerende grammatikker i bibelsk hebraisk $(\mathrm{BH})$, som er beregnet på første- og andenårsstuderende, sætter den studerende i stand til at læse og få indtryk af de bibelske tekster og disses grundlæggende grammatik, går nærværende lærebog dybere. Den er målrettet til viderekomne, som søger øget forståelse af de sproglige enkeltdele såvel som sammenhænge og baggrunde. Bogen er udstyret med en bred vifte af for faget uundværlige terminologiske betegnelser så som eng. he locale, cohortative og waw consecutive, som dog også som regel findes i andre lærebøger.

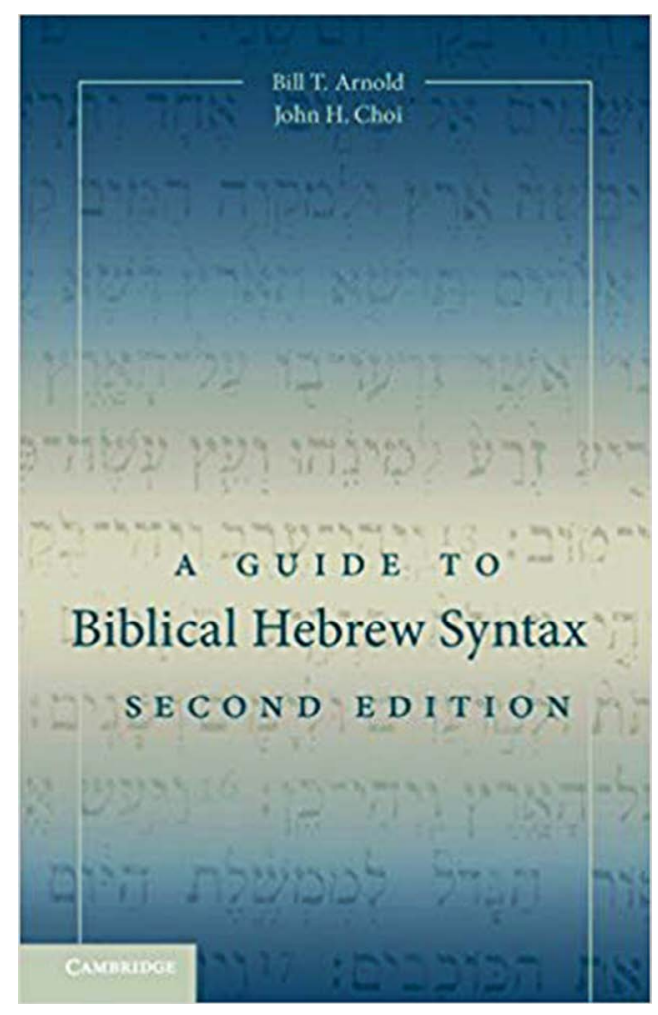

Således er denne akademiske bog, fra et lingvistisk-filologisk synspunkt såvel som fra et teologisk, både praktisk og nyttig, da den formidler en god dybde i grammatikken samt en god forståelse af BH's væsen såvel som sprogets finesser og opbygning. $\mathrm{Og}$ en sådan forståelse må jo gå forud for vellykket eksegese og hermeneutik. Forfatterne anfører 
da også, at som sprog og kommunikationsmiddel står $\mathrm{BH}$ såvel som de bibelske tekster os langt væk i tid og kultur - og netop derfor er dette at danne mening ud af sætningerne (teksterne) af største betydning.

A Guide to Biblical Hebrew Syntax følger et nyttig princrip, som er typisk for genren "grammatikbøger" inden for hebraisk: Den er struktureret i sin opbygning. Dette er med til at skabe kohærens i læseoplevelsen såvel som mulighed for fordybelse. Læser man bogen fra ende til anden, skulle man komme igennem "alle" BH's byggesten.

Efter to korte forord og en kortere indledning følger et kapitel om substantiver, dernæst kapitler om verber, siden "partikler" (som er en samlekasse for alle andre ordklasser) samt et kapitel om sætningsopbygning. Bogens fokus er på syntaks, hvilket ord også netop indgår i titlen.

Hver syntaktisk kategori begynder med en grundig definition heraf. Dette efterfølges af en liste med de mest almindelige eksegetiske anvendelser af det pågældende grammatiske fænomen. Dette skaber præcision såvel som nuancer. Kapitel 5 om syntaks og de mange sætningstyper indledes med disse ord:

Thus far in this book we have treated the syntax of individual words and phrases. By "phrases" we mean the function of individual words and the way they relate to each other in larger units to create noun phrases, verb phrases, adverbial phrases, and prepositional phrases. In most cases, a phrase is a series of words capable of serving the syntactical function of a single word. In this final section, we move beyond phrases to clauses and sentences [...]

Because Hebrew finite verbs contain implied subjects (embedded by means of pronominal morphemes), the subject and predicate of a clause are both contained in the verb, making it impossible to study verbal syntax without considering clauselevel relationships (pp. I 74f.).

Dermed aktualiserer forfatterne, hvorfor syntaks er vigtig, og hvorfor der er sammenhæng mellem en sætnings enkeltkomponenter og dens helhed. Og herfra går bogen i dybden med en lang række forskellige sætningstyper, som er vigtige i de bibelske tekster, eksempelvis eng. interrogative, oath og wish sentences.

Forfatterne giver læseren gode "mellemregninger", som man ikke altid får i denne type bøger. Dette er en fordel, fordi man dermed kan forstå emnet eller det partikulære grammatiske fænomen i en større sammenhæng og eventuelt uddybe eller nuancere sin viden. Jeg vil give et eksempel herpå. Det er kendt, at $\mathrm{BH}$ har to infinitiver, nemlig hhv. eng. infinitive construct og infinitive absolute. Bogen anfører ganske relevant dette: "Even though the two Hebrew infinitives appear similar in form, they had different origins and histories" (p. 86).

Dette er et eksempel på, hvad jeg kalder en mellemregning, som altså er en slags baggrundsdiskussion, der bidrager med nyttig baggrundsviden. Med mindre man har forsket specifikt i hebraisk eller semitisk infinitiv, kunne man forledes til at tro, at de to infinitiver på $\mathrm{BH}$, der kan minde om hinanden, har samme oprindelse, men det har de ikke. I forlængelse heraf forklares forskellene mellem disse to, og dermed forskellene i betydning og hvorledes man skal oversætte dem.

Generelt forklarer $A$ Guide to Biblical Hebrew Syntax komplekse grammatiske træk ved $\mathrm{BH}$ på en klar og overskuelig måde. Tilgangen er yderst pracis uden at være lakonisk. Lærebogen er krydret med den seneste forskning på området. Den har ligeledes en åben tilgang, fordi den også inkluderer andre opfattelser end den traditionelle eller end forfatternes. 
Med til at styrke formidlingen er bogens dokumentation i form af adækvat eksempelmateriale, der illustrerer de specifikke grammatiske fænomener, der behandles. Eksemplerne er taget direkte fra Tanakh/GT og primært sådanne, der hidrører fra $\mathrm{BH}$, men enkelte dog stammende fra sen $B H(\mathrm{LBH})$, undertiden for at vise sprogets udvikling.

Jeg har ikke meget at udsætte på bogen. Den er velskrevet, indsigtsfuld og fagligt præcis med velvalgte, illustrative eksempler. Terminologien er adækvat. Der er mange referencer, og de faktuelle oplysninger er pålidelige. Yderst få steder optræder en uregelmæssighed i vokalisering (det er jo udfordringen ved denne type bøger) - men det er altså ikke udpræget. Den vante læser vil givetvis nok opdage, hvis vokalen $\mathrm{O}$ i form af et cholem et sted er sat forkert - eller der kan opstå tvivl, om der mangler et dagesh.

Alt i alt kan jeg se mange fordele ved denne lærebog: Læseoplevelsen er behagelig, fordi den giver overblik og klarhed. Uanset om det sker via hurtige opslag i de to indekser over emner og skriftsteder eller fordybende prosalæsning, opfylder bogen til fulde sit formål, nemlig dette at gestalte en brugbar guide til BH's syntaks som nøgle til dybere lingvistisk forståelse samt som teologisk redskab for hermeneutik.

A Guide to Biblical Hebrew Syntax kan derfor varmt anbefales viderekomne udi deres hebraiskstudier. Også forskere kan have glæde af bogen, da megen viden er koncentreret her samt ajourført pr. 2018.

FLEMMING ANDRÉ PHILIP RAVN dansk sprogforsker, hebraist, lektor og forfatter 